\title{
Pharmacological Isolation and Characterization of NMDA Receptor- Mediated Synaptic Potential in the Dentate Gyrus of Rat Hippocampal Slices
}

\author{
Kazuho Abe and Hiroshi Saito \\ Department of Chemical Pharmacology, Faculty of Pharmaceutical Sciences, The University of Tokyo, Tokyo I13, Japan
}

Received October 16, 1992 Accepted January 7, 1993

\begin{abstract}
We attempted to observe the dentate gyrus field potential evoked by low-frequency stimulation of the perforant path in $\mathrm{Mg}^{2}$-free medium and identify the $N$-methyl-D-aspartate (NMDA) receptormediated synaptic potential using rat hippocampal slices. When perfusing solution was changed from normal medium ( $1.3 \mathrm{mM} \mathrm{Mg}^{2+}$ ) to $\mathrm{Mg}^{2+}$-free medium, the evoked potential was greatly increased and secondary population spikes appeared following a primary population spike. The evoked potential recorded in $\mathrm{Mg}^{2-}$-free medium was only partly blocked by 6-cyano-7-nitroquinoxaline-2,3-dione (CNQX), a nonNMDA receptor antagonist. The CNQX-resistant component of the evoked potential in $\mathrm{Mg}^{2+}$-free medium was completely abolished by $30 \mu \mathrm{M}$ DL-2-amino-5-phosphonovalerate, a NMDA receptor antagonist, indicating that the NMDA receptor-mediated synaptic response can be isolated by masking the non-NMDA receptor-mediated component of the evoked potential under the $\mathrm{Mg}^{2+}$-free condition. The isolated NMDA receptor-mediated synaptic potential was also blocked by 7-chlorokynurenate, an antagonist at the glycine site of the NMDA receptor, and restored by the concomitant presence of glycine. Observation of pharmacologically isolated NMDA receptor-mediated synaptic potential is a simple and good method for studying the direct effects of drugs on NMDA receptor-mediated responses.
\end{abstract}

Keywords: $N$-methyl-D-aspartate (NMDA) receptor, Synaptic potential, Dentate gyrus, $\mathrm{Mg}^{2+}$

In the central nervous system, the $N$-methyl-D-aspartate (NMDA) type of glutamate receptor plays important roles in processes such as the generation of long-term potentiation ( $1-5)$, spatial learning $(6-8)$, epilepsy $(9$, $10)$ and glutamate neurotoxicity $(11-13)$. Recent autoradiographic studies have revealed that NMDA receptors are present at higher density in the CAl region and the dentate gyrus of the hippocampus (14-16). Properties of NMDA receptor-mediated synaptic responses in the hippocampus have been studied extensively in the Schaffer collateral-CAl pyramidal cell synapses, but are not well studied in the perforant path-dentate gyrus granule cell synapses.

NMDA receptors do not contribute appreciably to excitatory synaptic responses evoked by low-frequency stimulation under normal conditions, because $\mathrm{Mg}^{2+}$ blocks the cation influx through the NMDA receptor-associated channel in a voltage-dependent manner $(17,18)$. Coan and Collingridge (19) have reported that lowfrequency, NMDA receptor-mediated synaptic responses can be reliably observed in the Schaffer collateral-CA1 pyramidal cell synapses when $\mathrm{Mg}^{2+}$ is omitted from the extracellular medium. This $\mathrm{Mg}^{2+}$-free model is a simple and good method for studying direct effects of drugs on the NMDA receptor-mediated synaptic responses. In the present study, we attempted to observe the dentate gyrus field potentials evoked by low-frequency stimulation of the perforant path in $\mathrm{Mg}^{2+}$-free medium and identify the NMDA receptor-mediated synaptic responses using a NMDA receptor antagonist, DL-2-amino-5-phosphonovalerate (APV), and a non-NMDA receptor antagonist, 6-cyano-7-nitroquinoxaline-2,3-dione (CNQX). As a result, we succeeded to isolate the NMDA receptormediated synaptic potentials evoked by low-frequency stimulation in the dentate gyrus. Furthermore, it is known that the NMDA receptor channel complex contains a glycine modulatory site and that modulation by glycine is essential for the opening of the NMDA receptor-associated cation channel $(20-22)$. Therefore, we further characterized the pharmacological properties 
of the isolated NMDA receptor-mediated synaptic potentials in the dentate gyrus including the regulation by $\mathrm{Mg}^{2+}$ and glycine.

\section{MATERIALS AND METHODS}

The hippocampi were quickly isolated from male Wistar rats, 8- to 10-week-old, and cut manually into transverse slices of $400-$ to $500-\mu \mathrm{m}$ thickness. The slices were allowed to recover for more than $1 \mathrm{hr}$ in an incubation chamber containing artificial cerebrospinal fluid (ACSF) which was maintained at $34^{\circ} \mathrm{C}$ and continuously oxygenated with $95 \% \mathrm{O}_{2}-5 \% \mathrm{CO}_{2}$. The composition of ACSF was as follows: $124.0 \mathrm{mM} \mathrm{NaCl}, 5.0 \mathrm{mM} \mathrm{KCl}, 2.4$ $\mathrm{mM} \mathrm{CaCl} 2,1.3 \mathrm{mM} \mathrm{MgSO}, 1.24 \mathrm{mM}, \mathrm{KH}_{2} \mathrm{PO}_{4}, 26.0$ $\mathrm{mM} \mathrm{NaHCO} 3$ and $10.0 \mathrm{mM}$ glucose.

Each slice was transferred into a recording chamber $(1.5 \mathrm{ml})$ in which warmed $\left(34^{\circ} \mathrm{C}\right)$ and oxygenated $\left(95 \% \mathrm{O}_{2}\right.$ $-5 \% \mathrm{CO}_{2}$ ) ACSF was continuously perfused at a rate of $1.4 \mathrm{ml} / \mathrm{min}$. Stimulation to the perforant path was delivered through bipolar tungsten electrodes positioned across the fibers, and the evoked potential was extracellularly recorded from the granule cell layer of the dentate gyrus (Fig. 1A). A glass capillary microeletrode filled with $0.9 \% \mathrm{NaCl}$ (tip resistance 5-7 Mohms) was used for the recording. A single test stimulation ( $0.05 \mathrm{msec}$ duration) was applied at intervals of $60 \mathrm{sec}$. The stimulus intensity was set so that the amplitude of the population spike was $50 \%$ of the maximum in normal ACSF and was not changed throughout the experiment. To observe NMDA receptor-mediated synaptic responses, we used the ACSF with no added $\mathrm{MgSO}_{4}\left(\mathrm{Mg}^{2+}\right.$-free ACSF $)$. All drugs were delivered by perfusion.

As shown in Fig. 1B, the evoked potential recorded from the dentate gyrus granule cell layer is composed of slow positivity and sharp negativity. The slow positivity reflects mainly excitatory postsynaptic potential (EPSP), which is generated in dendritic spines and spreads along the dendrites, but is termed the positive component in this report, because possible contamination of the inhibitory somatic response cannot be completely neglected. The sharp negativity is a result of the synchronous firing of the granule cells, and this is generally termed the population spike. To quantify changes of evoked potentials, we employed the following parameters: 1) the amplitude of positive component, 2) the amplitude of the population spike, 3) latency of the population spike peak, 4) the number of population spikes, 5) half-decay time of the positive component. The way of measuring these parameters is described in Fig. 1B in detail. APV was purchased from Sigma Chemical Co. (St. Louis, MO, USA). CNQX and 7-chlorokynurenate (7-Cl-Kyn) were purchased from Tocris Neuramin, Ltd. (Bristol, UK). Other chemicals were obtained from Wako Pure Chemical Industries, Ltd. (Osaka).

\section{RESULTS}

First we investigated the influence of omitting extracellular $\mathrm{Mg}^{2+}$ on synaptically evoked potentials in the dentate gyrus. The typical result is shown in Fig. 2. When perfusing solution was changed from normal ACSF (1.3 mM
A

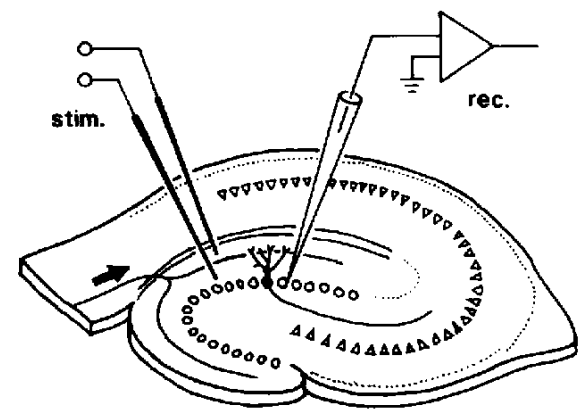

B

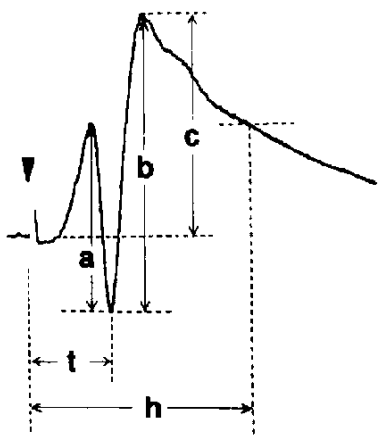

Fig. 1. Recording of evoked potential in the dentate gyrus of the rat hippocampal slice. A: schematic illustration of a transverse slice of rat hippocampus showing locations of stimulating and recording electrodes. B: a typical field potential recorded from the dentate gyrus granule cell layer. The time of application of test stimulation is indicated by a black arrow head. The voltage difference between the first positive peak and the succeeding negative peak was measured (a). Next, the voltage difference between the negative peak and the second positive peak was measured (b). The amplitude of the population spike was defined as $(\mathbf{a}+\mathbf{b}) / 2$. The amplitude of the positive component was defined as the voltage difference between the basal potential level and the positive peak (c). The latency of the population spike was defined as the time difference from the start of stimulation to the negative peak $(t)$. The half-decay time of the positive component was defined as $h$. 
A

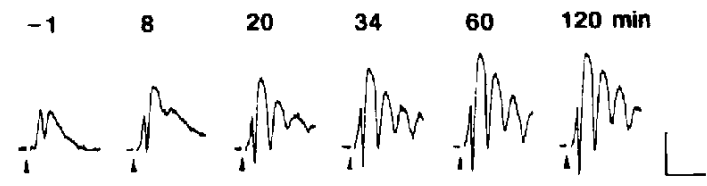

B

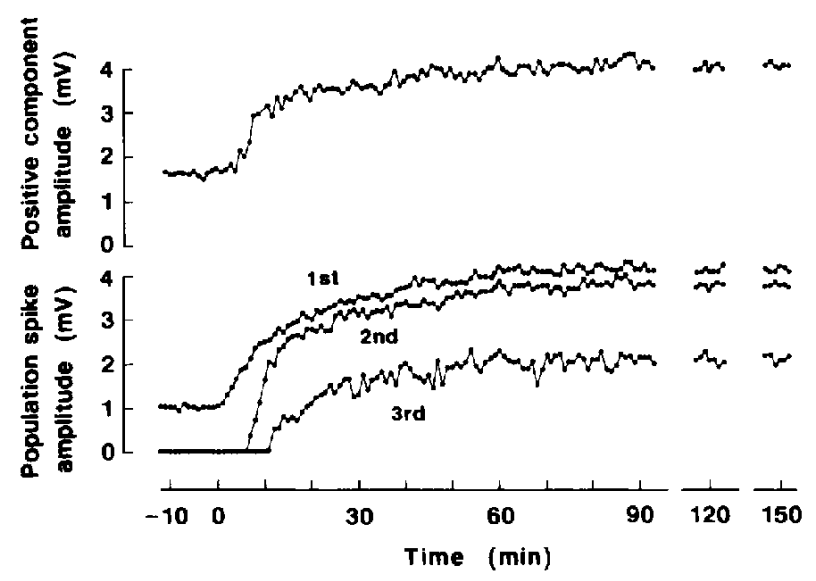

A

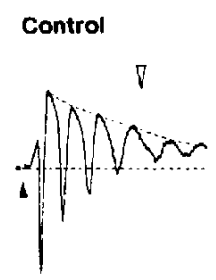

$30 \mu \mathrm{M}$ APV

$\mathbf{B}$

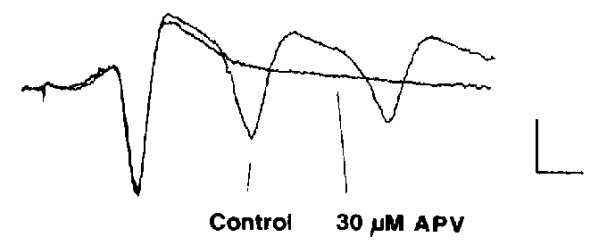

Fig. 2. The effect of omitting $\mathrm{Mg}^{2+}$ on the dentate gyrus field potential evoked by single stimulation of the perforant path at intervals of 60 $\mathrm{sec}$. The stimulus intensity was adjusted so that the amplitude of the primary population spike was $50 \%$ of the maximum in normal ACSF and was not changed throughout the experiment. A: typical single records, taken $1 \mathrm{~min}$ before and $8,20,34,60$ and $120 \mathrm{~min}$ after the start of perfusion with $\mathrm{Mg}^{2+}$-free ACSF. Stimulus artifacts have been blanked for clarity, and the time of stimulation is indicated by black arrow heads. Calibration bars: vertical, $2 \mathrm{mV}$; horizontal, $10 \mathrm{msec}$. B: timecourse of changes of evoked potential in a typical experiment. The upper graph shows the amplitude of the positive component, and the lower shows the amplitude of the first (1st), second (2nd) and third (3rd) population spikes. Perfusing medium was changed from normal ACSF to $\mathrm{Mg}^{2-}$-free ACSF at time 0 .
C
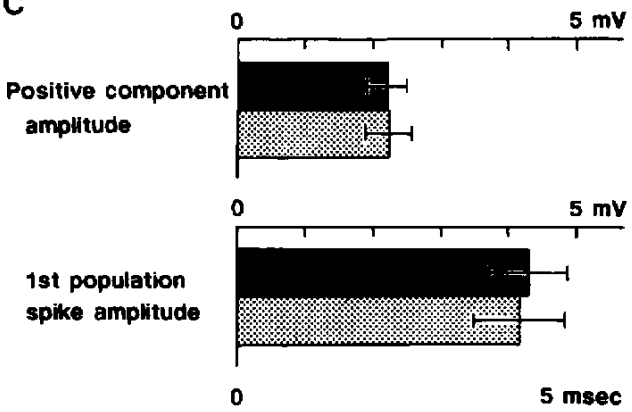

1st population spike latency
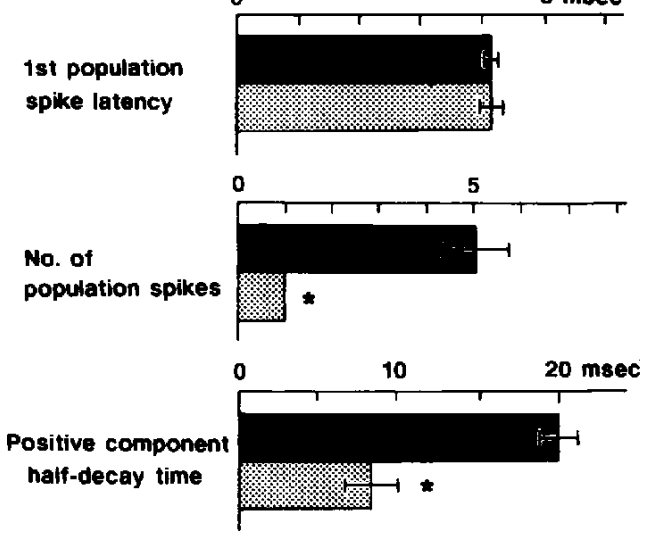

Fig. 3. The effect of $30 \mu \mathrm{M}$ APV on the synaptic response recorded in $\mathrm{Mg}^{2+}$-free ACSF. The field potential evoked by half maximum stimulation was first recorded in normal ACSF, and the slice was perfused with $\mathrm{Mg}^{2+}$-free ACSF. After the response reached the steady state (approximately 60 min after introduction of $\mathrm{Mg}^{2+}$-free ACSF), $30 \mu \mathrm{M} \mathrm{APV}$ was added in $\mathrm{Mg}^{2+}$-free ACSF. A: typical single records of evoked potentials in $\mathrm{Mg}^{2+}$-free ACSF before and 15 min after addition of $30 \mu \mathrm{M}$ APV. Halfdecay time of the positive component was indicated by the white arrow head. Vertical and horizontal calibration bars indicate 2 $\mathrm{mV}$ and $10 \mathrm{msec}$, respectively. B: the time scale of the records in A was expanded, and the records in the absence and presence of APV were superimposed. Vertical and horizontal calibration bars indicate $2 \mathrm{mV}$ and $2 \mathrm{msec}$, respectively. C: the influences of $30 \mu \mathrm{M}$ APV on the amplitude of the positive component, the amplitude of the first population spike, the latency of the first population spike, the number of the population spikes and the decay-half time of the positive component. Solid black and stippled columns are the data before and $15 \mathrm{~min}$ after addition of $30 \mu \mathrm{M}$ APV, respectively. The data are represented as the mean \pm S.E.M. of 5 observations. Asterisks indicate significant differences from the respective controls (solid black columns): ${ }^{*} \mathrm{P}<0.01$, paired $t$-test. 
$\mathrm{Mg}^{2+}$ ) to $\mathrm{Mg}^{2+}$-free ACSF, the amplitude of the positive component and population spike greatly increased. Furthermore, the decay of the positive component became much slower, and secondary population spikes, which were never observed in normal ACSF, appeared following a primary population spike. The increased responses usually took $40-60 \mathrm{~min}$ to reach the steady state. The amplitude of the positive component and primary population spike became $226.2 \pm 18.5 \% \quad(n=12)$ and 382.7 $\pm 40.4 \%(n=12)$ of those in normal ACSF, respectively. The maximum number of population spikes elicited varied among the slices from 2 to 16 , and the mean number of population spikes observed in $\mathrm{Mg}^{2+}$-free ACSF was $5.6 \pm 1.4(n=12)$. The responses in $\mathrm{Mg}^{2+}$-free ACSF could be observed stably for more than $2.5 \mathrm{hr}$ in all of the 12 tested slices.

Next we investigated the effects of APV, a selective NMDA receptor antagonist, and CNQX, a selective non-
A

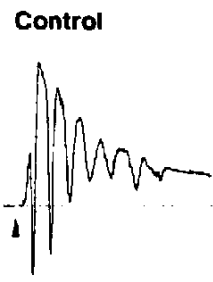

10 pM CNOX

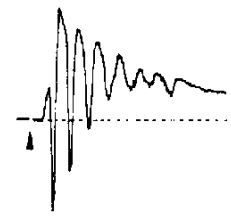

B

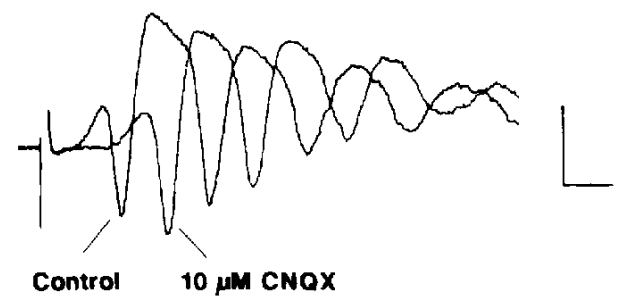

C

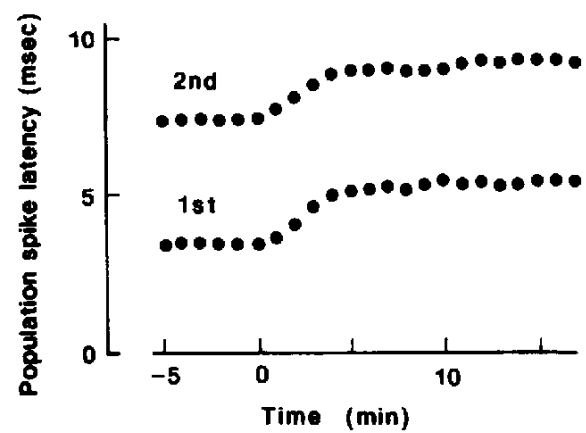

D

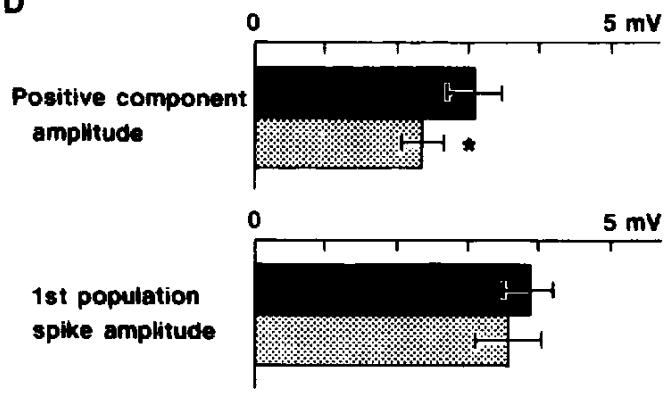

0

1st population spike latency
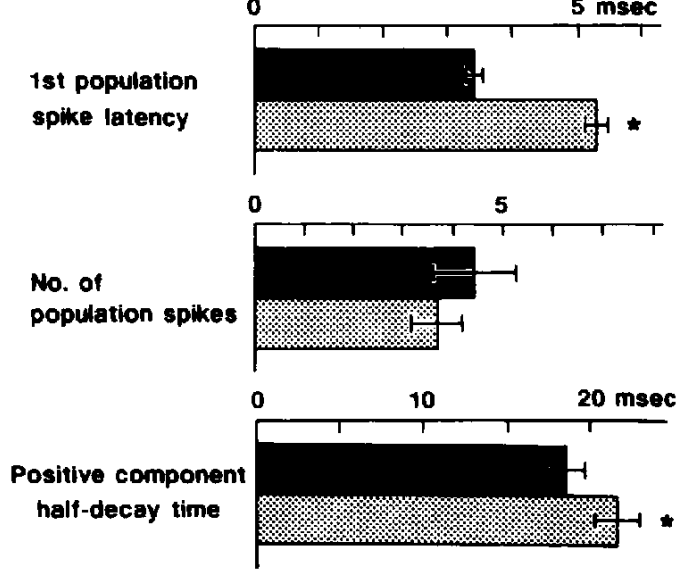

Fig. 4. The effect of $10 \mu \mathrm{M} \mathrm{CNQX}$ on the synaptic response recorded in $\mathrm{Mg}^{2+}$-free ACSF. After the slices were perfused with $\mathrm{Mg}^{2+}$-free ACSF for $60 \mathrm{~min}, 10 \mu \mathrm{M} \mathrm{CNQX}$ was added. A: typical single records of evoked potentials in $\mathrm{Mg}^{21}$-free ACSF before and $15 \mathrm{~min}$ after addition of $10 \mu \mathrm{M} \mathrm{CNQX}$. Vertical and horizontal calibration bars indicate $2 \mathrm{mV}$ and $10 \mathrm{msec}$, respectively. B: the time scale of the records in A was expanded and superimposed to clarify the change of the latency of population spikes. Vertical and horizontal calibration bars indicate $2 \mathrm{mV}$ and $2 \mathrm{msec}$, respectively. C: time-course of change of evoked potential was shown in terms of the latericy of the first (1st) and second (2nd) population spike. CNQX was added to $\mathrm{Mg}^{2+}$-free $\mathrm{ACSF}$ at time 0 . D: the influences of $10 \mu \mathrm{M} \mathrm{CNQX}$ on the amplitude of the positive component, the amplitude of the first population spike, the latency of the first population spike, the number of population spikes and the half-decay time of the positive component. Solid black and stippled columns are the data before and $15 \mathrm{~min}$ after addition of $10 \mu \mathrm{M} \mathrm{CNQX}$, respectively. The data are represented as the mean \pm S.E.M. of 9 observations. Asterisks indicate significant differences from the respective controls (solid black columns): ${ }^{*} \mathrm{P}<0.01$; paired $t$-test. 
NMDA receptor antagonist, on the evoked potential recorded in $\mathrm{Mg}^{2+}$-free ACSF. Figure 3 shows the effect of APV on the evoked potential recorded in $\mathrm{Mg}^{2+}$-free ACSF. When APV was added in $\mathrm{Mg}^{2+}$-free ACSF, the decay of the positive component became much faster and secondary population spikes completely disappeared, indicating that development of slow EPSP and appearance of secondary population spikes in the $\mathrm{Mg}^{2+}$-free condition are mediated by NMDA receptors. The onset of the positive component and the amplitude and latency of the first population spike were not influenced by APV at all. Interestingly, the positive component and the primary population spike in $\mathrm{Mg}^{2+}$-free $\mathrm{ACSF}$ supplemented with APV were larger than those in normal ACSF, indicating that the responses not mediated by NMDA receptors were also enhanced by omitting extracellular $\mathrm{Mg}^{2+}$. On the other hand, CNQX at $10 \mu \mathrm{M}$ completely blocked the evoked potentials in normal ACSF (data not shown), but the evoked potential recorded in $\mathrm{Mg}^{2+}$-free ACSF was only partly blocked by $10 \mu \mathrm{M}$ CNQX (Fig. 4). After addition of CNQX, the onset of the positive component became slower and the latency to the population spike became longer, confirming that development of fast EPSP is mediated by non-NMDA receptors. The amplitude of the positive component partly decreased and the halfdecay time of the positive component was apparently elongated. Secondary population spikes were not blocked by CNQX. These changes were immediately produced after addition of CNQX and reached the steady state within 15 min (Fig. 4C). The component resistant to $10 \mu \mathrm{M}$ CNQX was also not blocked by a higher concentration $(25 \mu \mathrm{M})$ of CNQX. As shown in Fig. 5, APV blocked the CNQXresistant component of the evoked potential in $\mathrm{Mg}^{2+}$-free ACSF in a concentration-dependent manner. The $\mathrm{IC}_{50}$ values for APV in terms of the amplitude of the positive component and population spikes were $7.41 \pm 1.22 \mu \mathrm{M}$ $(\mathrm{n}=5)$ and $1.99 \pm 0.49 \mu \mathrm{M}(\mathrm{n}=5)$, respectively, and the CNQX-resistant component was completely abolished by APV at $30 \mu \mathrm{M}$. These results clearly suggest that NMDA receptor-mediated synaptic responses can be isolated as a CNQX-resistant component of evoked potential in the absence of extracellular $\mathrm{Mg}^{2+}$.

We further characterized the pharmacologically isolated NMDA receptor-mediated synaptic potential recorded

A

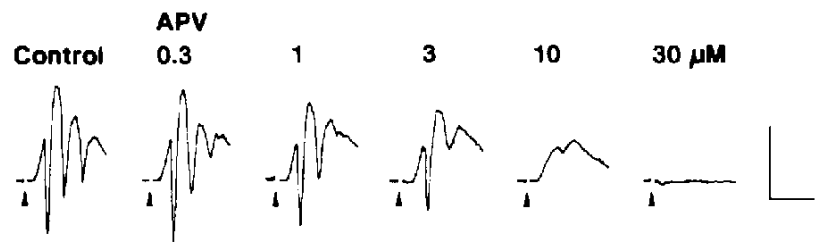

B

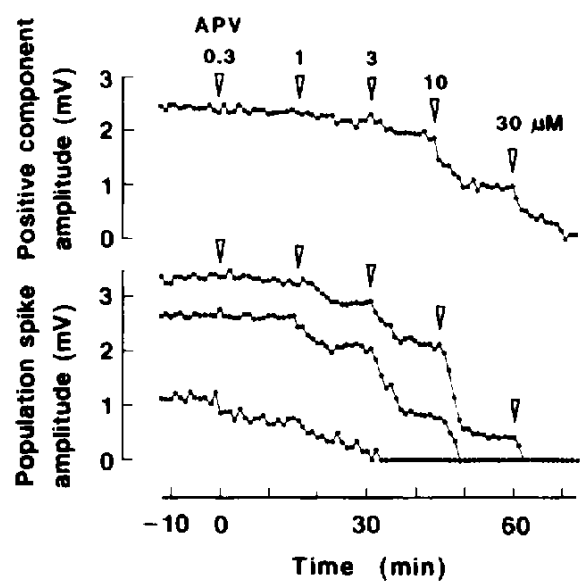

C

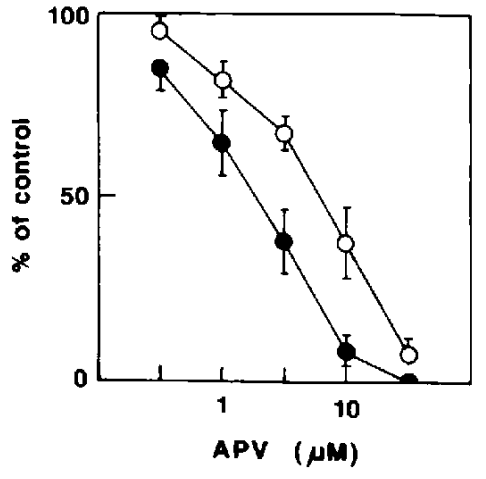

Fig. 5. The effect of APV on the field potential recorded in $\mathrm{Mg}^{21}$-free ACSF containing $10 \mu \mathrm{M} \mathrm{CNQX}$. The slices were perfused with $\mathrm{Mg}^{2-}$-free ACSF for $40 \mathrm{~min}$ and subsequently with $\mathrm{Mg}^{2+}$-free ACSF containing $10 \mu \mathrm{M}$ CNQX for 20 min. After the stability of the responses was confirmed for at least $10 \mathrm{~min}$, APV was cumulatively introduced in the perfusing solution. A: typical single records before $(0)$ and after addition of APV $(0.3-30 \mu \mathrm{M})$. Vertical and horizontal calibration bars indicate $2 \mathrm{mV}$ and 10 msec, respectively. B: time-course of the change in evoked potential was shown in terms of the amplitude of the positive component and first to third population spikes. The time of APV addition is indicated by white arrow heads. The data in A and B originated from the same experiment. C: concentration-response curve for APV. The amplitude of the positive component ( ()$)$ and the total amplitude of the first to third population spikes $(O)$ were expressed as a percentage of the control values (before addition of APV). The data are represented as the mean \pm S.E.M. of 5 observations. 
A

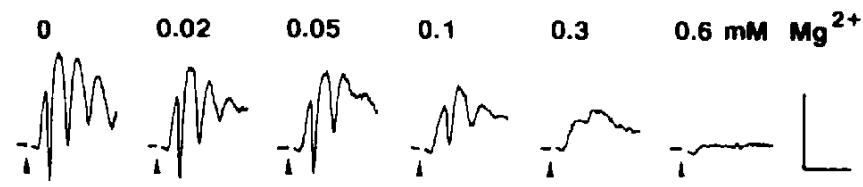

$\mathbf{B}$

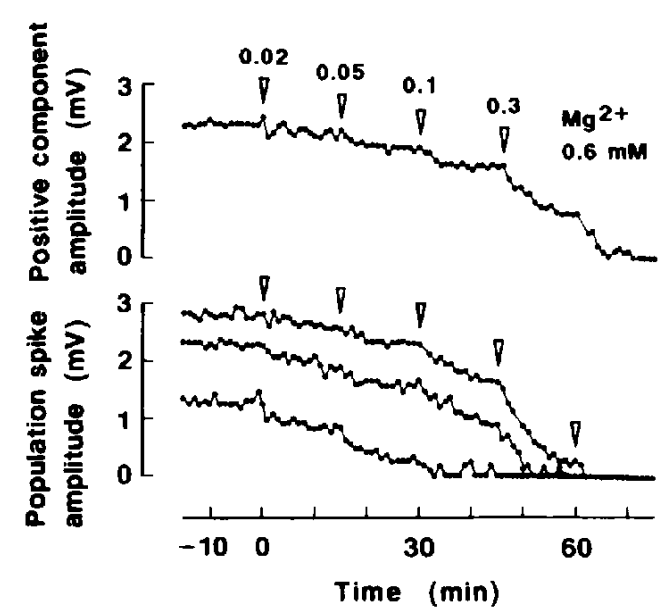

C

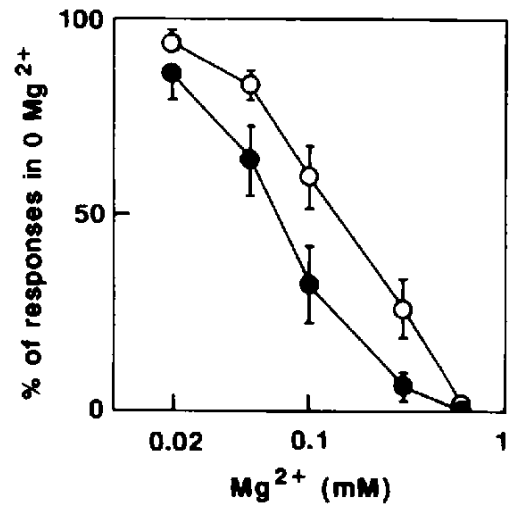

Fig. 6. The effect of increasing concentrations of $\mathrm{Mg}^{2+}$ on the isolated NMDA receptor-mediated synaptic potential. To observe the NMDA receptor-mediated component, the slices had been perfused with $\mathrm{Mg}^{2+}$-free $\mathrm{ACSF}$ for $40 \mathrm{~min}$ and subsequently with $\mathrm{Mg}^{2+}$-free ACSF plus $10 \mu \mathrm{M} \mathrm{CNQX}$ for $20 \mathrm{~min}$. After the stability of the responses was confirmed for a further 10 min, the influence of $\mathrm{Mg}^{2-}$ was examined by cumulatively introducing $\mathrm{MgSO}_{4}$ in the perfusing medium. The style of the graph is the same as in Fig. 5. The data in $C$ are the mean \pm S.E.M. of 6 observations.

A

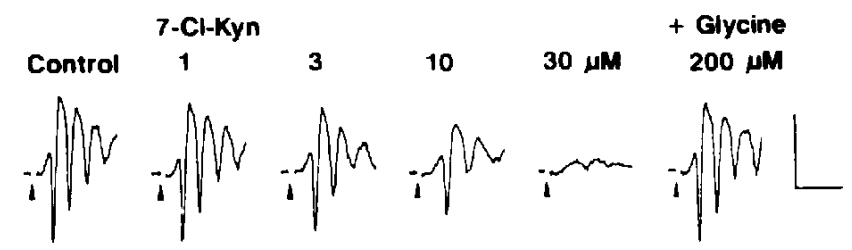

B

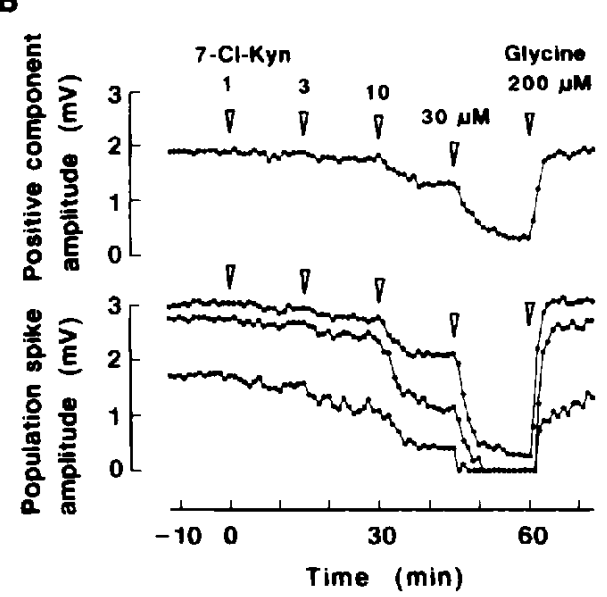

C

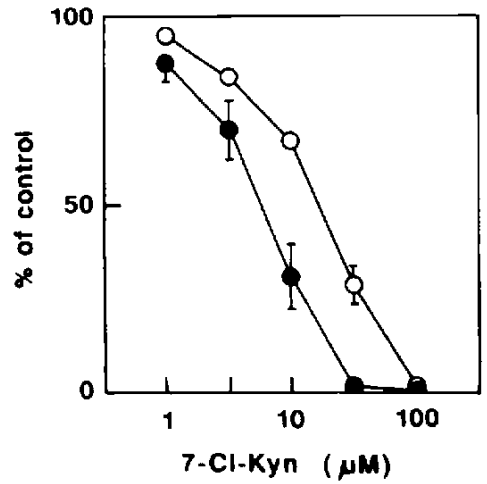

Fig. 7. The effect of 7-Cl-Kyn on the isolated NMDA receptor-mediated synaptic potential. The experimental procedure and the graph style were the same as in Fig. 6. In the experiment shown in A and B, $200 \mu \mathrm{M}$ glycine was further added after $30 \mu \mathrm{M} 7$ Cl-Kyn. The data in $\mathrm{C}$ are the mean \pm S.E.M. of 5 observations. 
in $\mathrm{Mg}^{2+}$-free ACSF containing $10 \mu \mathrm{M}$ CNQX. Figure 6 shows the effect of $\mathrm{Mg}^{2+}$ on the isolated NMDA receptormediated synaptic response. Increasing concentration of $\mathrm{Mg}^{2+}$ blocked the isolated NMDA receptor-mediated synaptic response in a concentration-dependent manner. The inhibitory effect of $\mathrm{Mg}^{2+}$ was seen from $0.02 \mathrm{mM}$, and the population spikes almost disappeared in the presence of $0.3 \mathrm{mM} \mathrm{Mg}^{2+}$. Complete inhibition of the positive component required a higher concentration $(0.6 \mathrm{mM})$ of $\mathrm{Mg}^{2-}$. The $\mathrm{IC}_{50}$ values for $\mathrm{Mg}^{2+}$ in terms of the amplitude of the positive component and population spikes were $0.159 \pm 0.036 \mathrm{mM}(\mathrm{n}=6)$ and $0.075 \pm 0.019 \mathrm{mM}(\mathrm{n}=6)$, respectively. As shown in Fig. 7, the isolated NMDA receptor-mediated synaptic potential was blocked by 7 Cl-Kyn, a selective antagonist at the glycine site of the NMDA receptor, in a concentration-dependent manner. The positive component and population spikes completely disappeared in the presence of $100 \mu \mathrm{M} 7-\mathrm{Cl}-\mathrm{Kyn}$. The blocking effect of 7-Cl-Kyn was reversed by addition of glycine, indicating that 7-Cl-Kyn acted selectively and competitively on the glycine site. $\mathrm{The}_{\mathrm{IC}} \mathrm{C}_{50}$ values for $7-\mathrm{Cl}$ Kyn in terms of the amplitude of the positive component and population spikes were $14.20 \pm 0.79 \mu \mathrm{M}(\mathrm{n}=5)$ and $5.22 \pm 1.16 \mu \mathrm{M}(\mathrm{n}=5)$, respectively.

\section{DISCUSSION}

The most remarkable changes of evoked potential in the dentate gyrus after omitting extracellular $\mathrm{Mg}^{2+}$ were 1) increase of positive component, 2) increase of population spike amplitude, 3) elongation of decay of positive component and 4) appearance of secondary population spikes. Pharmacological characterization with APV and CNQX of the synaptic potential in $\mathrm{Mg}^{2+}$-free medium revealed that the NMDA receptors participate in the slow EPSP component and the appearance of secondary spikes. Blockade of fast EPSP by CNQX resulted in a slowed onset of the positive component and delayed generation of action potential (population spike). The CNQXresistant component was identified as the synaptic responses purely mediated by NMDA receptors, since it was completely blocked by APV. It appears that activation of NMDA receptors alone can produce a depolarization large enough to generate action potentials in the dentate gyrus granular neurons. NMDA receptors largely contribute to neuronal excitability if only it is released from the $\mathrm{Mg}^{2+}$ block.

Coan and Collingridge (19) have reported that, when the evoked potential was recorded from the CA1 region in $\mathrm{Mg}^{2+}$-free medium, spontaneous population spike discharges were sometimes observed, and the evoked potential suddenly disappeared in rare cases. In preliminary experiments, we also observed some cases where the in- creased responses in the CAl region in $\mathrm{Mg}^{2+}$-free ACSF gradually decreased or suddenly disappeared. However, such an event was never observed in the case of the dentate gyrus synapses. These differences may be due to vulnerability of the CA1 pyramidal neurons or synaptic properties including neural networks. Since properties of NMDA receptor-mediated synaptic potential in the dentate gyrus seemed to be virtually the same as those in the CA1 region, vulnerability of CA1 pyramidal neurons may be determined by differences of intracellular mechanisms. Comparison of the evoked potentials in the $\mathrm{Mg}^{2+}$-free condition between the $\mathrm{CAl}$ region and the dentate gyrus may provide useful information on the cause of epileptiform activity or neuronal cell death.

Furthermore, we investigated the effects of $\mathrm{Mg}^{21}$ and 7Cl-Kyn on the pharmacologically isolated NMDA receptor-mediated synaptic potential in the dentate gyrus. $\mathrm{Mg}^{2+}$ blocked the isolated NMDA receptor-mediated response in the low micromolar range. $\mathrm{Mg}^{2+}$ is known to affect neurotransmitter release, but the effect observed in the present study is probably due to blocking of NMDA receptor-associated cation channels, because it requires millimolar concentrations to reduce neurotransmitter release (23). The isolated NMDA receptor-mediated synaptic potential was completely blocked by 7-Cl-Kyn and restored by concomitant application of exogenous glycine, indicating that the NMDA receptor-mediated synaptic response in the dentate gyrus was absolutely supported by endogenous glycine. The concentrations of $\mathrm{Mg}^{2+}$ and 7$\mathrm{Cl}-\mathrm{Kyn}$ effective for blocking the isolated NMDA receptor-mediated response in the dentate gyrus were very similar to those effective for blocking the evoked potential in the CAl region in $\mathrm{Mg}^{2+}$-free medium $(19,24)$. Modulation of NMDA receptors by $\mathrm{Mg}^{2+}$ and glycine in the perforant path-dentate granule cell synapses seems to be virtually the same as that in the Schaffer collateral-CA1 pyramidal cell synapses.

To study the drug effects on the NMDA receptormediated events, investigators have often examined influences on the responses induced by application of glutamate or NMDA. However, it remains possible that the responses induced by exogenously applied amino acids are different from those by endogenous glutamate released during synaptic transmission. Observing the synaptic field potential evoked by low-frequency stimulation in $\mathrm{Mg}^{2+}$-free medium is a simple method for directly studying synaptically-evoked, NMDA receptor-mediated responses. Furthermore, we successfully isolated the NMDA receptor-mediated component of synaptic transmission in the dentate gyrus by masking the non-NMDA receptor-mediated component with CNQX. Observation of the isolated NMDA receptor-mediated synaptic field potential should be useful for studying the effects of 
drugs on NMDA receptor-mediated synaptic responses or the functional changes of the NMDA receptor channel complex during some physiological and pathological events.

\section{REFERENCES}

1 Collingridge, G.L., Kehl, S.J. and McLennan, H.: Excitatory amino acids in synaptic transmission in the Schaffer collateralcommissural pathway of the rat hippocampus. J. Physiol. (Lond.) 334, 33-46 (1983)

2 Harris, E.W., Ganong, A.H. and Cotman, C.W.: Long-term potentiation in the hippocampus involves activation of $\mathrm{N}$ methyl-D-aspartate receptors. Brain Res. 323, 132-137 (1984)

3 Stringer, J.L., Hackett, J.T. and Guynett, P.G.: Long-term potentiation blocked by phencyclidine in vitro. Eur. J. Pharmacol. 98, 381-388 (1984)

4 Coan, E.J., Saywood, W. and Collingridge, G.L.: MK-801 blocks NMDA receptor mediated synaptic transmission and long-term potentiation in rat hippocampal slices. Neurosci. Lett. 80, 111-114 (1987)

5 Errington, M.L., Lynch, M.A. and Bliss, T.V.P.: Long-term potentiation in the dentate gyrus: induction and glutamate release are blocked by $\mathrm{D}(-)$ aminophosphonovalerate. Neuroscience 23, 279-284 (1987)

6 Morris, R.G.M., Anderson, E., Lynch, G.S. and Baudry, M.: Selective impairment of learning and blockage of long-term potentiation by an $N$-methyl-D-aspartate receptor antagonist, AP5. Nature 319, 774-776 (1986)

7 Butelman, E.R.: A novel NMDA antagonist, MK-801, impairs performance in a hippocampal-dependent spatial learning task. Pharmacol. Biochem. Behav. 34, 13-16 (1989)

8 Watanabe, Y., Himi, T., Saito, H. and Abe, K.: Involvement of glycine site associated with the NMDA receptor in hippocampal long-term potentiation and acquisition of spatial memory in rats. Brain Res. 582, 58-64 (1992)

9 Croucher, M.J., Collins, J.F. and Meldrum, B.S.: Anticonvulsant action of excitatory amino acid antagonists. Science 216, 899-901 (1982)

10 Peterson, D.W., Collins, J.F. and Bradford, H.F.: Anticonvulsant action of amino acid antagonists against kindled hippocampal seizures. Brain Res. 311, 176-180 (1984)

11 Choi, D.W., Maulucci-Gedde, M. and Kriegstein, A.R.: Glutamate neurotoxicity in cortical cell culture. J. Neurosci. 7,
$357-368(1987)$

12 Choi, D.W., Koh, J.-Y. and Peters, S.: Pharmacology of glutamate neurotoxicity in cortical cell culture: attenuation by NMDA antagonists. J. Neurosci. 8, $185-196$ (1988)

13 Freese, A., DiFiglia, M., Koroshetz, W.J., Beal, M.F. and Martin, J.B.: Characterization and mechanism of glutamate neurotoxicity in primary striatal cultures. Brain Res. 521, $254-$ 264 (1990)

14 Monaghan, D.T. and Cotman, C.W.: Distribution of $N$ methyl-D-aspartate-sensitive $\mathrm{L}-\left[{ }^{3} \mathrm{H}\right]$ glutamate-binding sites in rat brain. J. Neurosci. 5, 2909-2919 (1985)

15 Greenamyre, J.T., Olson, J.M.M., Penney, J.B., Jr. and Young, A.B.: Autoradiographic characterization of $N$-methylD-aspartate-, quisqualate- and kainate-sensitive glutamate binding sites. J. Pharmacol. Exp. Ther. 233, 254-263 (1985)

16 Maragos, W.F., Penney, J.B. and Young, A.B.: Anatomic correlation of NMDA and ${ }^{3} \mathrm{H}$-TCP-labeled receptors in rat brain. J. Neurosci. 8, 493-501 (1988)

17 Mayer, M.L., Westbrook, G.L. and Guthrie, P.B.: Voltage-dependent block by $\mathrm{Mg}^{2+}$ of NMDA responses in spinal cord neurons. Nature 309, 261-263 (1984)

18 Nowak, L., Bregestovski, P., Ascher, P., Herbet, A. and Prochiantz, A.: Magnesium gates glutamate-activated channels in mouse central neurons. Nature 307, 462-465 (1984)

19 Coan, E.L. and Collingridge, G.L.: Characterization of an $N$ methyl-D-aspartate receptor component of synaptic transmission in rat hippocampal slices. Neuroscience 22, 1-8 (1987)

20 Johnson, J.W. and Ascher, P.: Glycine potentiates the NMDA response in cultured mouse brain neurons. Nature $\mathbf{3 2 5}$, $529-533$ (1987)

21 Ransom, R.W. and Stec, N.L.: Cooperative modulation of [ ${ }^{3} \mathrm{H}$ ]MK-801 binding to the $N$-methyl-D-aspartate receptor-ion channel complex by L-glutamate, glycine, and polyamines. $\mathrm{J}$. Neurochem. 51, 830-836 (1988)

22 Forsythe, I.D., Westbrook, G.L. and Mayer, M.L.: Modulation of excitatory synaptic transmission by glycine and zinc in cultures of mouse hippocampal neurons. J. Neurosci. 8, 3733 - 3741 (1988)

23 Katz, B. and Miledi, R.: A study of spontaneous miniature potentials in spinal motoneurons. J. Physiol. (Lond.) 168, $389-422$ (1963)

24 Bashir, Z.I., Tam, B. and Collingridge, G.L.: Activation of the glycine site in the NMDA receptor is necessary for the induction of LTP. Neurosci. Lett. 108, 261-266 (1990) 